University of Nebraska - Lincoln

DigitalCommons@University of Nebraska - Lincoln

1995

\title{
Evaluation of Four Intermediate Wheatgrass Populations under Grazing
}

\author{
Kenneth J. Moore \\ lowa State University \\ Kenneth P. Vogel \\ University of Nebraska-Lincoln, kvogel1@unl.edu \\ Terry J. Klopfenstein \\ University of Nebraska-Lincoln, tklopfenstein1@unl.edu \\ Robert A. Masters \\ USDA-ARS \\ Bruce E. Anderson \\ University of Nebraska-Lincoln
}

Follow this and additional works at: https://digitalcommons.unl.edu/usdaarsfacpub

Moore, Kenneth J.; Vogel, Kenneth P.; Klopfenstein, Terry J.; Masters, Robert A.; and Anderson, Bruce E., "Evaluation of Four Intermediate Wheatgrass Populations under Grazing" (1995). Publications from USDAARS / UNL Faculty. 1898.

https://digitalcommons.unl.edu/usdaarsfacpub/1898

This Article is brought to you for free and open access by the U.S. Department of Agriculture: Agricultural Research Service, Lincoln, Nebraska at DigitalCommons@University of Nebraska - Lincoln. It has been accepted for inclusion in Publications from USDA-ARS / UNL Faculty by an authorized administrator of DigitalCommons@University of Nebraska - Lincoln. 


\title{
Evaluation of Four Intermediate Wheatgrass Populations under Grazing
}

\author{
Kenneth J. Moore,* Kenneth P. Vogel, T. J. Klopfenstein, Robert A. Masters, and Bruce E. Anderson
}

\begin{abstract}
The grazing season in the central and northern Great Plains could be extended by use of adapted cool-season grass pastures for spring and fall grazing to augment the native warm-season range. A grazing trial was conducted to evaluate the forage quality of four intermediate wheatgrass [Thinopyrum intermedium (Host) Barkw. \& D.R. Dewey] populations for use in forage-livestock systems. The cultivars Slate and Oahe and two populations selected for improved IVDMD, 'Manska' and NE TI 1, were evaluated. Each population was seeded in the fall of 1987 in three replicated 0.4-ha pastures arranged in a randomized complete block design. Pastures were stocked with three beef yearlings for $28 \mathrm{~d}$ in spring 1989 and $42 \mathrm{~d}$ in spring 1990 to provide a stocking rate of 7.5 steers $\mathrm{ha}^{-1}$. Duration of grazing was shorter in 1989 because of inadequate soil moisture. Average daily gain (ADG) and gain per hectare were higher $(P \leq 0.10)$ in 1989 than 1990 , despite the lower $(P \leq 0.10)$ forage availability and lesser number of grazing days in 1989. Steers grazing Manska in 1989 gained $1.59 \mathrm{~kg} \mathrm{~d}^{-1}$, compared with $1.42,1.27$, and 1.43 for Oahe, Slate, and NE TI 1, respectively. There were no differences $(P>0.10)$ in ADG or gain per hectare among populations in 1990. The improvement in ADG resulted in 30 to $65 \mathrm{~kg}$ more gain per hectare from Manska compared with the other populations in 1989. These results demonstrate the excellent quality of intermediate wheatgrass for grazing livestock and the impact that modest improvements in forage quality can have on animal performance.
\end{abstract}

$\mathrm{I}^{\mathrm{N}}$ NTERMEDIATE WHEATGRASSES [Thinopyrum intermedium (Host) Barkw. \& D.R. Dewey] are cool-season perennial grasses that are becoming increasingly important as hay and pasture grasses throughout much of the central and northern Great Plains of the USA and prairie provinces of Canada (Asay and Knowles, 1985). The species has both glabrous (subsp. intermedium) and pubescent (subsp. barbulatum) types, which are known as intermediate and pubescent wheatgrass, respectively. In the central Great Plains where the native rangeland is comprised primarily of warm-season grasses, intermediate wheatgrass is best utilized for spring and fall grazing in a complementary system with native rangeland. Intermediate wheatgrass can provide high quality forage for beef cows (Bos taurus L.) with calves and yearling cattle. It matures at a slower rate than crested wheatgrasses [Agropyron cristatum (L.) Gaertn. and A. desertorum (Fisch. ex Link) Schult.], which are also adapted to this region (Asay and Knowles, 1985). Intermediate wheatgrass has produced higher yields than crested wheatgrass in Nebraska when precipitation exceeded $380 \mathrm{~mm}$ (Vogel et al., 1987).

Intermediate wheatgrass is used predominantly as a pasture grass, but no previous research has compared intermediate wheatgrass populations in terms of relative animal performance and productivity. Evidence of differen-

K.J. Moore, Dep. of Agron., Iowa State Univ., Ames, IA 500II; K.P. Vogel and R.A. Masters, USDA-ARS and Dep. of Agronomy, T.J. Klopfenstein, Dep. of Animal Science, and B.E. Anderson, Dep. of Agronomy, Univ. of Nebraska, Lincoln, NE 68583. Joint contribution from USDA-ARS, Iowa Agric. and Home Econ. Exp. Stn., and the Nebraska Agric. Exp. Stn. Published as Paper no. 10381, Journal Series, Nebraska Agric. Exp. Stn. Received II June 1993. *Corresponding author (Email: kjmoore@iastate.edu).

Published in Agron. J. 87:744-747 (1995). ces among populations for IVDMD has been documented. Wurster et al. (1971) reported significant differences in IVDMD between forage of 'Oahe' and 'Greenar' intermediate wheatgrass. Vogel et al. (1986) reported substantial genetic variability for IVDMD among intermediate wheatgrass germplasm accessions evaluated in space plantings. In a subsequent study, 34 populations were evaluated in sward plots at three central Great Plains locations, representative of the climatic diversity of the region, to determine the relative magnitude of genotype and genotype $x$ environment interaction effects for forage yield and IVDMD (Vogel et al., 1993b). There were differences among populations for these traits. Genotype $\times$ location interaction effects were significant for forage yield, but were not significant for IVDMD, indicating that this trait is stable over environments. Though forage yields were not as consistent as IVDMD, some strains ranked consistently in the top one-third.

The overall objective of this experiment was to determine if two intermediate wheatgrass populations selected for high IVDMD produce superior animal gains and beef production per hectare when grazed by beef yearlings as compared with the two intermediate wheatgrass cultivars currently being used in the central Great Plains. Specific objectives were (i) to determine if there are differences in IVDMD and other measures of forage nutritive value among populations under grazing and (ii) to determine if observed differences in nutritive value among populations result in improved animal performance of growing steers.

\section{MATERIALS AND METHODS}

The populations evaluated included the cultivars Oahe, Slate, and Manska and the experimental population NE TI 1. Oahe was released by the South Dakota Experiment Station in 1961, and Slate was released jointly by the USDA-ARS and the Nebraska Experiment Station in 1969 (Hanson, 1972). These cultivars were selected for agronomic characteristics and are widely grown for forage throughout the central and northern Great Plains.

Manska was selected out of Mandan 759, a pubescent strain selected from PI 116252 that has had wide commercial use but has never been formally released as a cultivar (Berdahl et al., 1993). Manska was developed by the USDA-ARS at Mandan, ND, as a reselection of Mandan 759, which had become contaminated by outcrossing with other varieties and/or seed admixture. It was identified as having improved yield and IVDMD in field evaluations conducted at three locations in Nebraska in 1986 and 1987 (Vogel et al., 1993b). Manska was released by the USDA-ARS, USDA-SCS, North Dakota Agricultural Experiment Station, and the Agricultural Research Division, University of Nebraska (Berdahl et al., 1993). The experimental population NE TI 1, developed by K.P. Vogel, is based on six PI lines that had high yields and high IVDMD in replicated trials (Vogel et al., 1986, 1993b). Plants were selected from the six PI lines (PI 345586, 273732, 273733, 315353, 315067, and

Abbreviations: ADG, average daily gain; $\mathbf{C P}$, crude protein; IVDMD, in vitro dry matter digestibility; NDF, neutral-detergent fiber; NIRS, near infrared reflectance spectroscopy. 
315355) for high IVDMD and forage yield and were polycrossed to produce NE TI 1, which was then increased another generation to produce the Synthetic 2 generation seed used in this trial.

\section{Small-Plot Verification Trial}

A small-plot trial was conducted to verify that the newly created synthetic population NE TI 1 had improved IVDMD and to reconfirm the previously identified differences in IVDMD among Oahe, Slate, and Manska prior to conducting the grazing trial. The test contained six populations, including the four subsequently used in the grazing trial, and was conducted using conventional small-plot procedures as described by Vogel et al. (1993b). The experiment was established in 1985 at the University of Nebraska Agricultural Research and Development Center near Mead on a Sharpsburg silty clay loam soil (fine, montmorillonitic, mesic Typic Argiudolls). The experimental design was a randomized complete block with six replicates. Plot size was 1.5 by $4.5 \mathrm{~m}$. Plots were harvested following head emergence the last week of June 1986 and the first week of July 1987 with a flail-type plot harvester. A subsample was collected from each plot at harvest, dried in a forced-draft oven at $55^{\circ} \mathrm{C}$, and ground to pass a 1-mm screen in a shear mill.

\section{Pasture Trial}

Pastures were established in the fall of 1987 at the University of Nebraska Agricultural Research and Development Center near Mead on a Sharpsburg silty clay loam soil. Experimental units consisted of three 0.4 -ha pastures of each population, arranged in a randomized complete block design.

Pastures were grazed in 1989 and 1990 . Each spring, pastures were burned before grazing to remove any residual herbage from the previous season. Nitrogen fertilizer was applied when new growth began in the spring, at rates of $112 \mathrm{~kg} \mathrm{~N} \mathrm{ha}^{-1}$ in 1989 and $90 \mathrm{~kg} \mathrm{~N} \mathrm{ha}^{-1}$ in 1990 .

Pastures were grazed using similar stocking management as would be used by ranchers for complimentary systems with warmseason range. Each pasture was stocked with three crossbred steers, initially weighing $\approx 300 \mathrm{~kg}$, throughout the grazing period both years to provide a stocking rate of 7.5 steers ha ${ }^{-1}$. Before being assigned to pasture treatments, steers were fed a 50:50 alfalfa-corn (Medicago sativa L.-Zea mays L.) silage diet at $2 \%$ of body weight in a feedlot for $4 \mathrm{~d}$ and weighed at the end of Days 3 and 4 . Weights were averaged to determine initial weights, and steers were allotted to treatment by weight. The same feeding and weighing procedure was used following the grazing period to determine final weight in order to minimize any effects due to fill.

\section{Forage Sampling and Analysis}

Pastures were sampled on a weekly basis during the grazing period both years. Herbage mass was determined by clipping the forage at a height of $2.5 \mathrm{~cm}$ within six randomly assigned $0.74-\mathrm{m}^{2}$ subplots, and subsamples were collected for forage analyses. Samples collected from each pasture were composited, dried at $55^{\circ} \mathrm{C}$ in a forced-draft oven, and ground to pass a $1-\mathrm{mm}$ screen in a shear mill. The samples were subsequently reground in a cyclone mill fitted with a 1-mm screen to improve particle size uniformity.

Forage samples collected from the small-plot experiment were analyzed to determine concentrations of crude protein (CP) (AOAC, 1980), neutral-detergent fiber (NDF) (Goering and Van Soest, 1970), and IVDMD (Marten and Barnes, 1980). Forage samples collected from pastures were analyzed to determine IVDMD and concentrations of CP and NDF by NIRS using the protocol described by Windham et al., 1989. A subset of 60 samples were analyzed using the procedures cited above and were used to develop NIRS calibration equations. One-fourth of these samples were used as an independent set to validate calibrations developed from the other samples. Coefficients of determination and standard errors for calibration and validation were, respectively, 0.94, 2.05, and 2.25 for IVDMD; 0.99, 0.56, and 0.47 for $\mathrm{CP}$; and $0.98,1.29$, and 1.66 for NDF.

\section{Statistical Analysis}

Analysis of variance was used to assess the statistical significance of treatment effects due to population and sampling date (Anderson and McLean, 1974). Comparisons among improved populations and the cultivars were made using single degree of freedom contrasts (Steel and Torrie, 1980). All tests of significance were made at the 0.10 probability level.

\section{RESULTS AND DISCUSSION}

The small-plot trial verified that Manska and NE TI 1 were from 12 to $20 \mathrm{~g} \mathrm{~kg}^{-1}$ higher in IVDMD than Oahe and Slate (Table 1). Dry matter yields were greater for the improved populations than Oahe and Slate in 1986, but were similar in 1987. There were no differences detected among the populations for maturity (data not shown).

Precipitation received during the months preceding and during the grazing trials in 1989 and 1990 is presented in Fig. 1. In both years, the months of January through May were relatively dry, and soil moisture was deficient at initiation of grazing.

Grazing was initiated on 3 May in 1989. Steers were allowed to graze the pastures for $4 \mathrm{wk}$, at which time herbage mass became limiting due to inadequate soil moisture for growth (Fig. 2). In 1989, with the exception of one 28-mm rain, it remained dry throughout the 4-wk grazing period. In 1990, grazing was deferred until 15 May, to compensate for insufficient growth due to inadequate soil moisture. With the exception of the first few days, there was adequate soil moisture throughout the 1990 grazing period. Grazing was terminated after $6 \mathrm{wk}$, when herbage mass consisted primarily of senescent culms. Differences in precipitation between the years, therefore, afforded an excellent opportunity to evaluate the populations under two different environments.

\section{Herbage Mass}

Herbage production was limited throughout the 1989 grazing period by inadequate soil moisture (Fig. 2). No differences in herbage mass were observed among populations in 1989. Herbage mass was significantly greater

Table 1. Dry matter yield and in vitro dry matter digestibility (IVDMD) of four populations of intermediate wheatgrass grown in yield trials near Mead, NE.

\begin{tabular}{|c|c|c|c|c|c|c|}
\hline \multirow[b]{2}{*}{ Population } & \multicolumn{3}{|c|}{ Dry matter yield } & \multicolumn{3}{|c|}{ IVDMD } \\
\hline & 1986 & 1987 & Mean & 1986 & 1987 & Mean \\
\hline & \multicolumn{3}{|c|}{$\longrightarrow \mathrm{Mg} \mathrm{ha}^{-1}$} & \multicolumn{3}{|c|}{$-\mathrm{g} \mathrm{kg}^{-1}$} \\
\hline Oahe & 5.3 & 8.3 & 6.8 & 559 & 649 & 604 \\
\hline Slate & 5.3 & 8.2 & 6.8 & 549 & 645 & 597 \\
\hline Manska & 6.5 & 7.8 & 7.2 & 569 & 664 & 616 \\
\hline NE TI 1 & 6.5 & 8.6 & 7.5 & 568 & 668 & 618 \\
\hline SE† & 0.27 & 0.29 & 0.23 & 6 & 11 & 7 \\
\hline
\end{tabular}

$\dagger$ Standard error of the mean (appropriate for comparisons within a column). 


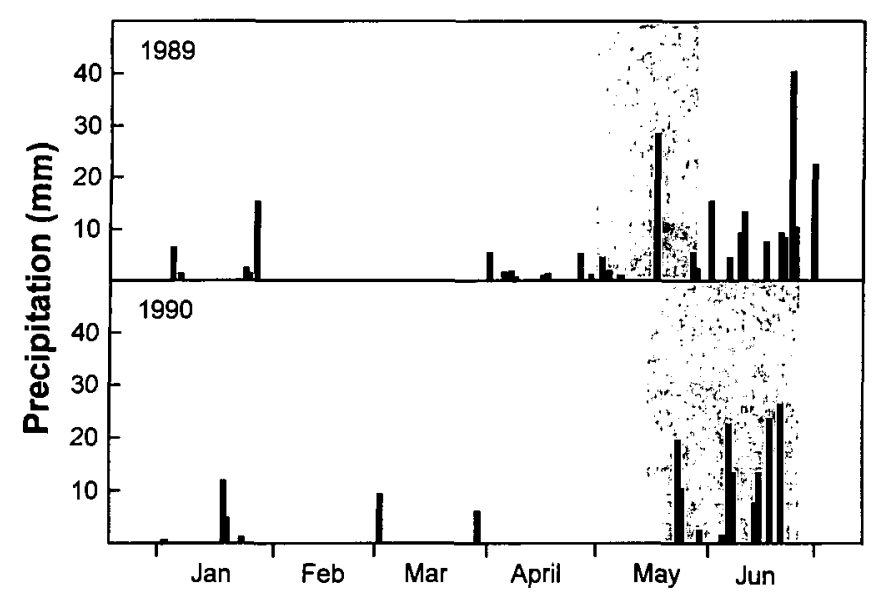

Fig. 1. Precipitation received at Mead, NE, in the months preceding and during grazing (shaded area) in 1989 and 1990.

during the 1990 grazing period (Fig, 2) than in 1989. At the initiation of grazing in 1990, approximately twice as much herbage mass was present than in 1989. Herbage mass was initially similar among populations in 1990, but began to decline more rapidly for the improved populations at $\approx 4 \mathrm{wk}$. Since the populations had similar yield potential in small plots, this decline was attributed to greater consumption by grazing livestock.

\section{Animal Performance}

Average daily gain and gain per hectare were higher for all populations in 1989 than 1990 (Table 2), despite the lower forage availability and lesser number of grazing days in 1989. Steers grazing Manska had the highest ADG and gain per hectare in 1989, but there were no differences in ADG or gain per hectare among populations in 1990. The improvement in ADG resulted in 30 to $65 \mathrm{~kg}$ more gain per hectare from Manska compared with the other populations in 1989. Gain per hectare was $15 \%$ greater for Manska in 1989 compared with the average of all of the other populations.

No previous grazing studies have been conducted comparing intermediate wheatgrass cultivars. A previous study comparing two crested wheatgrass cultivars, Nordan and Ruff, was conducted at Mead in an adjacent set of pastures from 1985 to 1987 (Vogel et al., 1993a). In that study,

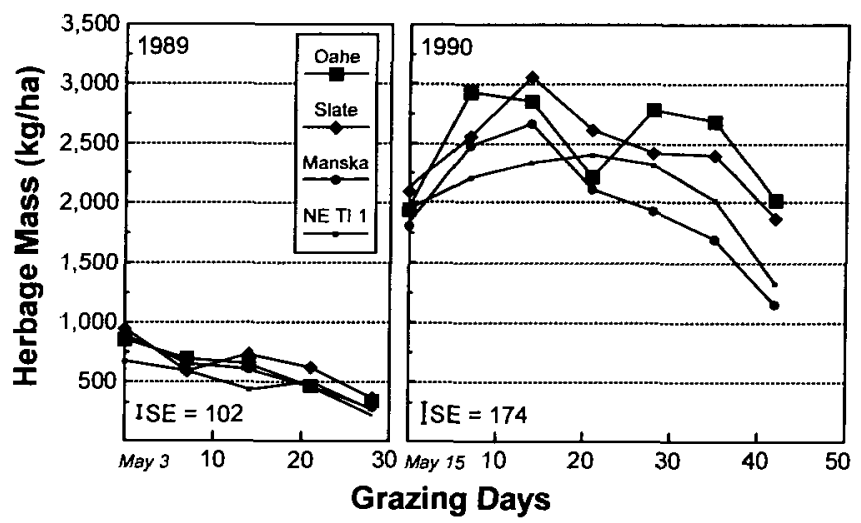

Fig. 2. Herbage mass of four intermediate wheatgrass populations grazed near Mead, NE, during 1989 and 1990.
Table 2. Average daily and total gains of steers grazing four populations of intermediate wheatgrass.

\begin{tabular}{|c|c|c|c|c|c|c|}
\hline \multirow[b]{2}{*}{ Population } & \multicolumn{3}{|c|}{ Average daily gain } & \multicolumn{3}{|c|}{ Total gain $\dagger$} \\
\hline & 1989 & 1990 & Mean & 1989 & 1990 & Mean \\
\hline & & $\mathrm{kg} \mathrm{d}^{-1}$ & & $\longrightarrow$ & $\mathrm{cg} \mathrm{ha}^{-1}$ & \\
\hline $\begin{array}{l}\text { Oahe } \\
\text { Slate } \\
\text { Manska } \\
\text { NE TI } 1\end{array}$ & $\begin{array}{l}1.42 \\
1.27 \\
1.59 \\
1.43\end{array}$ & $\begin{array}{l}0.72 \\
0.83 \\
0.86 \\
0.77\end{array}$ & $\begin{array}{l}1.06 \\
1.05 \\
1.22 \\
1.10\end{array}$ & $\begin{array}{l}294 \\
264 \\
329 \\
297\end{array}$ & $\begin{array}{l}221 \\
257 \\
268 \\
239\end{array}$ & $\begin{array}{l}257 \\
260 \\
298 \\
268\end{array}$ \\
\hline $\mathrm{SE} \ddagger$ & 0.044 & 0.097 & 0.069 & 9.1 & 30.2 & 19.7 \\
\hline
\end{tabular}

$\dagger$ Pastures were grazed for $4 \mathrm{wk}$ in 1989 and $6 \mathrm{wk}$ in 1990.

¥ Standard error of the mean (appropriate for comparisons within a column).

average daily gains and gains per hectare during the $3-\mathrm{yr}$ period were $1.3 \mathrm{~kg} \mathrm{~d}^{-1}$ and $258 \mathrm{~kg} \mathrm{ha}^{-1}$, respectively. Although direct comparisons between the two studies cannot be made, the gains per animal and per hectare for crested wheatgrass were similar to those achieved in the present study. In the crested wheatgrass study, Ruff produced higher gains per hectare over the $3 \mathrm{yr}$ of the study, due to better persistence. In the present intermediate wheatgrass trial, there were no differences in persistence among the populations. Basal cover was determined with an inclined 10-point frame at the beginning of the grazing period both years. There were no differences in basal cover $(\bar{x}=21.0$ $\% ; S_{\bar{x}}=1.0$ ) among populations or years.

\section{Forage Nutritive Value}

Few differences were observed in IVDMD, CP, or NDF among Slate, Manska, and NE TI 1 in 1989 (Fig. 3, 4, and 5); however, IVDMD and CP were lower, and NDF was higher, for Oahe than for the other cultivars throughout the grazing period.

There were few or no differences observed in IVDMD, $\mathrm{CP}$, and NDF among any of the populations during the 1990 grazing period (Fig. 3, 4, and 5). An initial increase in IVDMD occurred during the first week of grazing in 1990, due to a flush of growth brought on by rain (Fig. 1 and 2). Digestibility of the forage at the beginning of the trial was lower than during the previous year.

Differences in animal performance between years were attributed primarily to the large differences in digestible energy of herbage mass as measured by IVDMD. Digestibility of all populations in 1989 was initially $>800 \mathrm{~g} \mathrm{~kg}^{-1}$

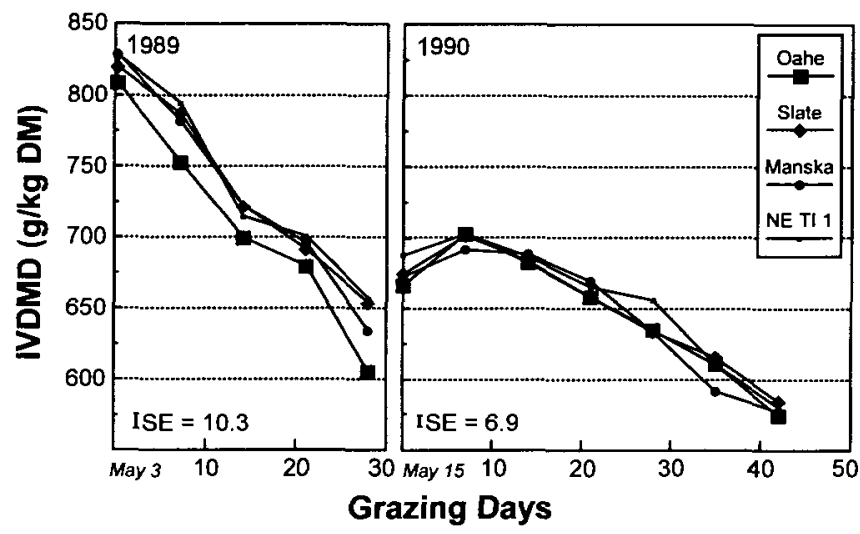

Fig. 3. In vitro dry matter digestibility (IVDMD) of available forage for four intermediate wheatgrass populations grazed near Mead, NE, during 1989 and 1990. 


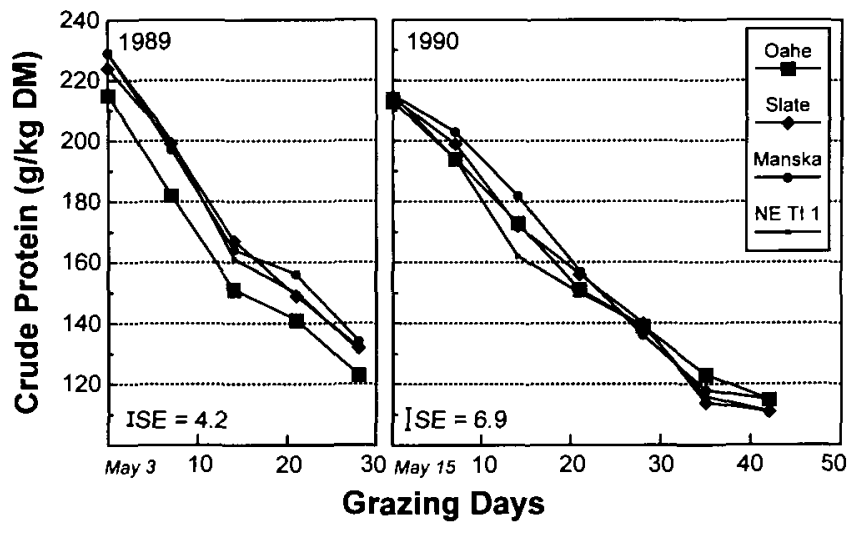

Fig. 4. Crude protein concentration of available forage for four intermediate wheatgrass populations grazed near Mead, NE, during 1989 and 1990.

and declined linearly during the grazing period. In 1990, IVDMD of all populations was $>700 \mathrm{~g} \mathrm{~kg}^{-1}$ at the initiation of grazing and also declined linearly with time, although at a slower rate than in 1989. Crude protein concentrations were initially high and remained above adequate levels for growth of yearling steers throughout the grazing period both years (NRC, 1984).

The differences in nutritive value between years can be explained by two factors, which are confounded: maturity of the forage at the initiation of grazing and the effect of drought which occurred in 1989 . The negative relationship between maturity and forage quality is widely recognized (Lechtenberg and Hemken, 1985). In 1989, IVDMD of ungrazed forage declined at an average rate of $3.7 \mathrm{~g} \mathrm{~kg}^{-1} \mathrm{~d}^{-1}$. Assuming a similar rate of decline for 1990, IVDMD would be expected to be $44.4 \mathrm{~g} \mathrm{~kg}^{-1}$ lower at the beginning of the trial that year due to the delay in the initiation of grazing.

Water stress has been demonstrated to increase forage quality in cool-season grasses. Sheaffer et al. (1992) reported that moisture stress increased $\mathrm{CP}$ and decreased NDF concentrations in reed canarygrass (Phalaris arundinacea L.), smooth bromegrass (Bromus inermis Leyss.), orchardgrass (Dactylis glomerata L.), and timothy (Phleum pratense L.). Bittman et al. (1988) reported that water stress

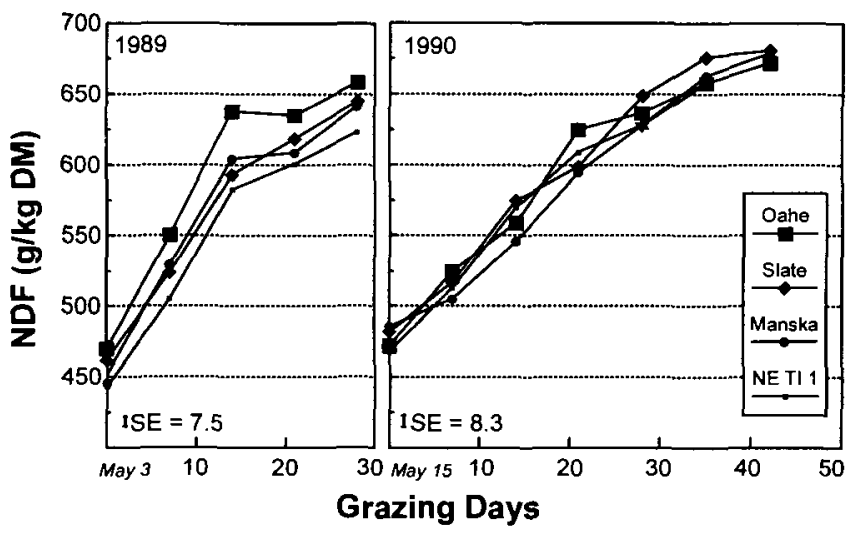

Fig. 5. Neutral detergent fiber (NDF) concentration of available forage for four intermediate wheatgrass populations grazed near Mead, NE, during 1989 and 1990. increased the IVDMD of crested wheatgrass and smooth bromegrass.

\section{CONCLUSIONS}

The results of these experiments demonstrate the excellent quality of intermediate wheatgrass as a forage for grazing livestock, as well as the impact that modest genetic improvements in forage quality can have on animal performance. They also demonstrate that there are factors that affect animal utilization of forages that are not measured by laboratory analyses commonly used to predict forage quality. This research also confirms the necessity of evaluating experimental pasture and range plants in grazing trials prior to release for commercial use. Results of this trial were instrumental in the decision to release Manska as a cultivar.

\section{REFERENCES}

Anderson, V.L., and R.A. McLean. 1974. Design of experiments: A realistic approach. Marcel Dekker, New York.

Association of Official Analytical Chemists. 1980. Official methods of analysis. 13th ed. AOAC, Washington, DC.

Asay, K.H., and R.P. Knowles. 1985. The wheatgrasses. p. 166-176. In M.E. Heath et al. (ed.) Forages: The science of grassland agriculture. 4th ed. Iowa State Univ. Press, Ames.

Berdahl, J.D., R.E. Barker, J.F. Karn, J.M. Krupinsky, I.M. Ray, K.P Vogel, K.J. Moore, T.J. Klopfenstein, B.E. Anderson, R.J. Haas, and D.A. Tober. 1993. Registration of 'Manska' pubescent intermediate wheatgrass. Crop Sci. 33:881.

Bittman, S., G.M. Simpson, and Z. Mir. 1988. Leaf senescence and seasonal decline in nutritional quality of three temperate forage grasses as influenced by drought. Crop Sci. 28:546-552.

Goering, H.K., and P.J. Van Soest. 1970. Forage fiber analysis. USDAARS Handb. 379. U.S. Gov. Print. Office, Washington, DC.

Hanson, A.A. 1972. Grass varieties in the United States. USDA-ARS Agric. Handb, 170. U.S. Gov. Print. Office, Washington, DC.

Lechtenberg, V.L., and R.W. Hemken. 1985. Hay quality. p. 460-469. In M.E. Heath et al. (ed.) Forages: The science of grassland agriculture, 4th ed. Iowa State Univ. Press, Ames.

Marten, G.C., and R.F Barnes. 1980. Prediction of energy digestibility of forages with in vitro rumen fermentation and fungal enzyme systems. p. 49-60. In W.J. Pigden et al. (ed.) Standardization of analytical methodology for feeds. Int. Development Res. Ctr., Ottawa, ON.

National Research Council. 1984. Nutrient requirements of beef cattle. 6th ed. National Academy Press, Washington, DC.

Sheaffer, C.C., P.R. Peterson, M.H. Hall, and J.B. Stordahl. 1992. Drought effects on yield and quality of perennial grasses in the north central United States. J. Prod. Agric. 5:556-561.

Steel, R.G.D., and J.H. Torrie. 1980. Principles and procedures of statistics: A biometrical approach. 2nd ed. McGraw-Hill Book Co., New York.

Vogel, K.P., B.C. Gabrielsen, J.K. Ward, B.E. Anderson, H.F. Mayland, and R.A. Masters. 1993a. Forage quality, mineral constituents, and performance of beef yearlings grazing two crested wheatgrasses. Agron. J. 85:584-590.

Vogel, K.P., H.G. Jung, and P.E. Reece. 1987. Performance and potential of intergeneric wheatgrass hybrids in the central Great Plains. Crop Sci. 27:8-13.

Vogel, K.P., P.E. Reece, and J.F.S. Lamb. 1986. Genotype and genotype $\times$ environment interaction effects for forage yield and quality of intermediate wheatgrass. Crop Sci. 26:653-658.

Vogel, K.P., P.E. Reece, and J.T. Nichols. 1993b. Genotype and genotype $X$ environment effects on forage yield and quality of intermediate wheatgrass in swards. Crop Sci. 33:37-41.

Windham, W.R., D.R. Mertens, and F.E. Barton II. 1989. Protocol for NIRS calibration: Sample selection and equation development and validation. p. 96-103. In G.C. Marten et al. (ed.) Near infrared reflectance spectroscopy (NIRS): Analysis of forage quality. USDA Agric. Handb. 643. U.S. Gov. Print. Office, Washington, DC.

Wurster, M.J., L.D. Kamstra, and J.G. Ross. 197I. Evaluation of cool season grass species using in vivo and in vitro techniques. Agron. J. $63: 241-245$. 